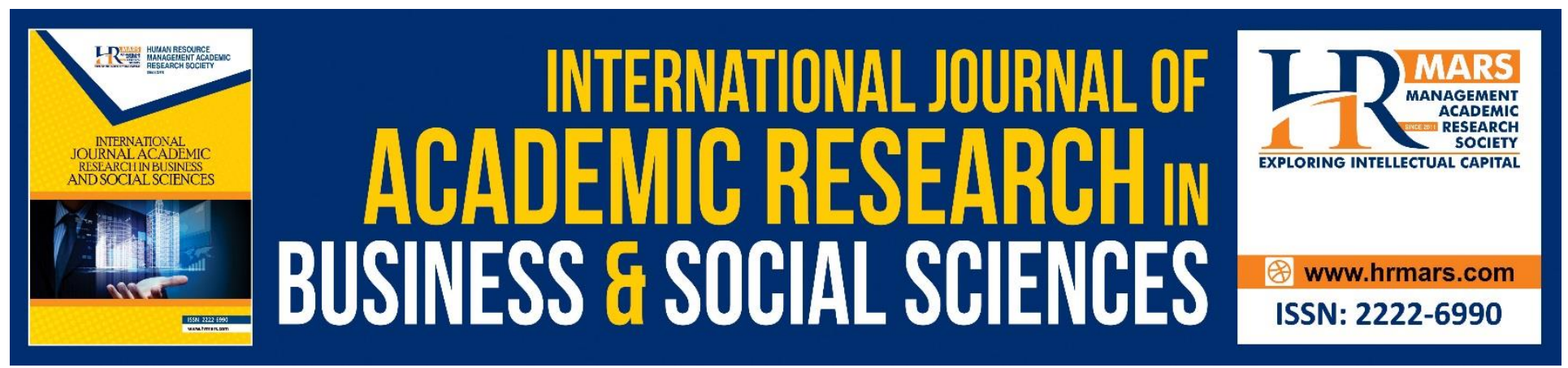

\title{
Influence of Philanthropic Corporate Social Responsibility Strategy on Perceived Firm Performance in Telecommunication Sector in Rwanda
}

Venerande Kayirangwa, G. S. Namusonge, Julius Warren Kule

To Link this Article: http://dx.doi.org/10.6007/IJARBSS/v8-i7/4328 DOI: $10.6007 /$ IJARBSS/v8-i7/4328

Received: 24 May 2018, Revised: 10 June 2018, Accepted: 29 June 2018

Published Online: 24 July 2018

In-Text Citation: (Kayirangwa, Namusonge, \& Kule, 2018)

To Cite this Article: Kayirangwa, V., Namusonge, G. S., \& Kule, J. W. (2018). Influence of Philanthropic Corporate Social Responsibility Strategy on Perceived Firm Performance in Telecommunication Sector in Rwanda. International Journal of Academic Research in Business and Social Sciences, 8(7), 116-132.

Copyright: (C) 2018 The Author(s)

Published by Human Resource Management Academic Research Society (www.hrmars.com) This article is published under the Creative Commons Attribution (CC BY 4.0) license. Anyone may reproduce, distribute, translate and create derivative works of this article (for both commercial and non-commercial purposes), subject to full attribution to the original publication and authors. The full terms of this license may be seen at: http://creativecommons.org/licences/by/4.0/legalcode

Vol. 8, No. 7, July 2018, Pg. 116 - 132

Full Terms \& Conditions of access and use can be found at http://hrmars.com/index.php/pages/detail/publication-ethics 


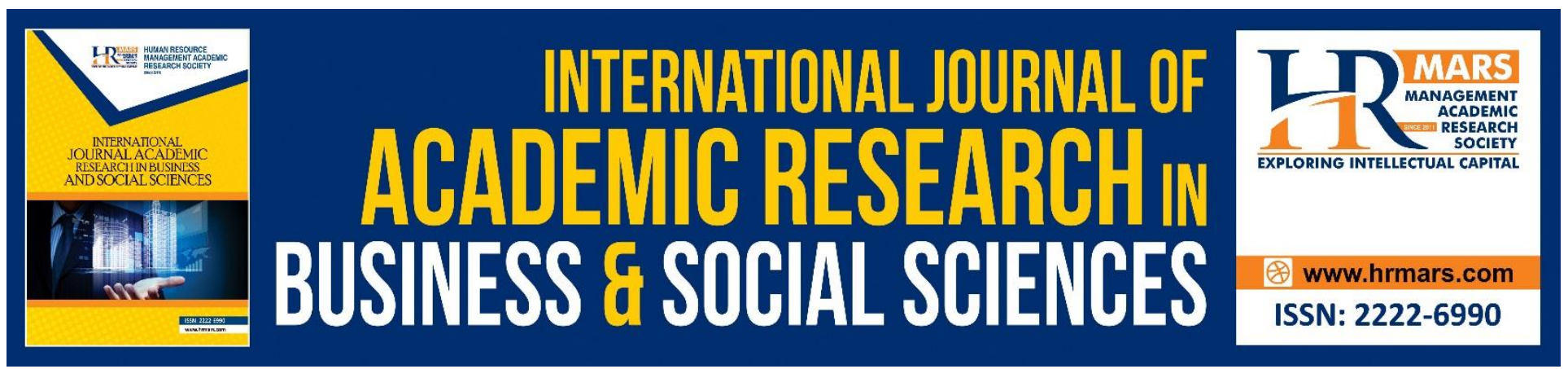

\title{
Influence of Philanthropic Corporate Social Responsibility Strategy on Perceived Firm Performance in Telecommunication Sector in Rwanda
}

\author{
Venerande Kayirangwa \\ PhD candidate, Department of Business Administration in the School of Business (STRATEGIC \\ MANAGEMENT), Jomo Kenyatta University of Agriculture and Technology, Kenya \\ Email: kayiven2000@yahoo.fr \\ Prof. G. S. Namusonge \\ Jomo Kenyatta University of Agriculture and Technology/ Nairobi-Kenya. \\ Email: gsnamusonge@gmail.com \\ Dr. Julius Warren Kule \\ Jomo Kenyatta University of Agriculture and Technology /Kigali-Rwanda.
}

\begin{abstract}
This study is concerned with Influence of philanthropic Corporate Social Responsibility strategy on Perceived firm Performance in telecommunication sector in Rwanda. To analyze the influence of strategic philanthropic on the targeted telecom firms' performance is the specific objective of the work. Qualitative and quantitative research design are used and performed by primary and secondary data collected from the targeted companies' managers and staff in charge of CSR through interview and questionnaires, and reports provided by these telecom companies and RURA recorded during years 2012-2016. Targeted population of the study was 228 managers and CSR related staff from MTN Rwanda (110), TIGO Rwanda (80) and AIRTEL Rwanda (38) to give sample size of 145 staff in question found by using stratified random sampling and all questionnaires were distributed where 114 of them were retrieved representing 79.1\%. This work used both inferential and descriptive statistics, and data are treated by using Excel and SPSS package while regressed model and correlation coefficients were utilized to analyze the relationship between variables. Results found show that all the telecommunication companies in Rwanda had the focus of improving the education, health and economic empowerment system in accomplishment of government priorities and they gained the public confidence, thus improve firm's image and reputation, increasing or retention of potential customers, benefited competitive advantage, and then after their profits. The findings revealed that, in combination with other factors like quality management, committed staff, quality and quantity of products, business environment, etc., CSR practices may improve perceived firm's performance.
\end{abstract}


INTERNATIONAL JOURNAL OF ACADEMIC RESEARCH IN BUSINESS AND SOCIAL SCIENCES

Vol. 8, No. 7, July 2018, E-ISSN: 2222-6990 @ 2018 HRMARS

Keywords: Corporate Social Responsibility, Philanthropic, Perceived Firm's Performance.

\section{Introduction}

Corporate social responsibility (CSR) is a recent phenomenon in the corporate world and has a bone of contention when it comes to academic study in terms of its identity. CSR is a commonly used term today that indicated community relations with a firm, especially in developed countries for large firms (Hamid \& Ruhaya, 2011). Besides conducting business activities and pursuing financial benefits, corporate bodies have also several other roles and responsibilities towards the society such as the social and environmental responsibilities and business contributions that would benefit the society at large (Margolis and Walsh, 2001).

Indeed, the concept of CSR and its variants; public accountability, corporate governance, corporate citizenship and corporate sustainability; have even found inroad application lately into the telecommunication sector (John, Victor \& Umoh, 2015). Zhang Weiping opines that "The goal of CSR should be to be a human centered company and achieve harmonious growth with the local community" (Maya Forstater et al., 2010). The term "corporate social responsibility" became popular in the 1960s and has remained a term used indiscriminately by many to cover legal and moral responsibility more narrowly construed (DeGeorge, 2010). For the decades, it has been seen that corporate social responsibility was voluntary works to some companies, but now due to rapid industrialization and competition, every business, small or big need to have corporate social responsibility policy in place .It has become a communication channel between customers and companies (Mudaheranwa et al., 2014).

In the 1970s business managers applied the traditional management functions when dealing with corporate social responsibilities (CSR) and community relations issues, while in the 1980s, business, social interest and community relations came closer and firms became more responsive to their stakeholders (Rosamaria, 2011). A modern concept of CSR has improved in the 1970s (Carroll, 1999). In the modern commercial of this world, firms and their managers are subjected to well publicize pressure to play an increasingly active role in society so called community relations (Carroll, 1999). The idea that business is part of society, and therefore has community and national responsibilities is established in the culture, and economic history of many African countries. Surveys of CSR amongst businesses in Africa have found that the most common approach to CSR issues is through philanthropic support, in particular focusing on education, health and environment (Maya Forstater et al., 2010). Some companies operating in Rwanda, especially telecommunication companies are practicing philanthropic strategy and spend huge amounts of money in their commitments to the community than their competitors, even when they operate in the same industry, and the government of Rwanda is also picking up interest in CSR by recognizing investors on the basis of their CSR initiatives. Generally, businesses in Rwanda incorporated explicit CSR strategies in their business models and policies (Guus et al., 2013).

\section{Problem Statement}

The fact that the researcher observes from the empirical literature, the different researchers from differente countries do not have same understanding on philanthropic CSR strategy practices and perceived firm performance of their case studies. For instance, Shoukat \& Muhammad (2014) sayed that telecommunication firms which implement CSR earn more profit for the long term periods, the study of John, Victor and Umoh (2015) showed that except staff welfare, significant relationship existed between Corporate Social Responsibility (CSR) and competitive advantage in 
telecommunication companies, which is the indicator of firm performance, but they did not indicate how philanthropic affect firm performance in developing countries as Rwanda, means here in Rwanda they also are not sufficient knowledge on the relationship between SCR and firm performance. This shows the subject of philanthropic practices and firm performance is tackled from various perspective.

This current study found a gap, whereby the above studies did not analyze the impact of corporate social responsibility practices on perceived firm performance based on philanthropic, as the best focuses of CSR. Even though RURA indicated that telecommunication companies in Rwanda, more in various activities of corporate social responsibilities ranging from education, health, sport,... but the reports do not show the real influence of CSR practices in this firm performance and also there are few (if not) studies in Rwanda indicated how CSR can facilitate business performance especially in telecommunication sector. From these, the researcher come up with an idea of carrying out a research called philanthropic corporate social responsibility and performance of telecommunication firms in Rwanda.

\section{Objectives of the Study}

To analyze the influence of philanthropic CSR strategy practices on perceived firm performance in telecommunication sector in Rwanda. Tofind relationship between philanthropic strategy and performance of telecommunication sector in Rwanda.

\section{Research Hypothesis}

1. $\mathrm{H}_{0}$ : Philanthropic practices do not affect performance of telecommunication sector in Rwanda.

\section{Justification of the Study}

The research provides information related to this topic, it is hoped that this study will act as a resource tool to both private and public sectors, especially telecommunication sector. To the researcher, this research can be useful for enhancing more knowledge about SCR and skills of doing research. The research comes up with remedies to problem resulting from poor CSR practices in Rwanda. The research results are meant to act as inputs to customer care mechanism in the process of building a good image for a company.

\section{Scope of the Study}

The study focuses on philanthropic strategy of Corporate Social Responsibility and perceived firm performance on telecommunication sector in Rwanda. It has been carried out in three telecommunication companies in Rwanda such as MTN located in Kigali City, Gasabo District, TIGO located in Kigali City, Nyarugenge district, and AIRTEL Rwanda located in Kigali City, Gasabo District. It covers the period between 2012 and 2016. This helps to ensure that research is specific to determine period of time because of access to information.

\section{Limitations of the Study}

During the process of this research, was encounter some constraints imposed on the researcher, as the study was carried among the different telecommunications companies in the regional, it was very difficult and limited to generalize the results of the study. Some managers were unwilling to reveal real financial performance information. However, this was mitigated through the use of perceptual measures that had the overall effect of allowing researcher to infer financial performance. Other 
INTERNATIONAL JOURNAL OF ACADEMIC RESEARCH IN BUSINESS AND SOCIAL SCIENCES

Vol. 8, No. 7, July 2018, E-ISSN: 2222-6990 @ 2018 HRMARS

respondents were needed to ensure if it is legal with the institution to answer such questions or to give true answers that might affect their job. However, the researcher used the possible mechanism to find the solutions.

\section{Literature Review}

The theories relevant to the philanthropic strategy have been written by different authors; they help on explanatory and give the information on Corporate Social Responsibility (CSR) and perceived firm performance. Philanthropic theory endeavors should be undergirded by a theory of philanthropy. The use of the term "theory" in both theory of change and theory of philanthropy emphasizes the value and importance of conceptual clarity. A theory of change hypothesizes how change occurs in the world. A theory of philanthropy articulates a foundation's role in supporting change.

The theory of philanthropy is a way for a foundation to make explicit what is often only implicit. This enables internal and external actors to explicitly pose significant questions and resolve key decision points, to understand and play important roles more fully and effectively, and to improve performance by enhancing alignment across complex systems both internally, and externally (Patton, 2011). In addition, this theory increases a foundation's effectiveness, self-knowledge ("makes the invisible visible"), coherence, and transparency externally; generates learning and capacity for future impact and adaptation to change.

In recent years, the Foundation Review and the Stanford Social Innovation Review, among others, have featured several articles on the importance of theories of change and strategic philanthropy (Behrens, 2009; Patrizi \& Thompson, 2010; Klugman, 2011; Culwell, Rodriguez, Croteau, \& Kakli, 2014; Brest, 2010; Forti, 2012; Colby, Stone, \& Carttar, 2004). Its approach is designed to help foundations align their strategies, governance, operating and accountability procedures, and grant making profile and policies with their resources and mission. A foundation's theory of philanthropy articulates how and why the foundation will use its resources to achieve its mission and vision. It also hypothesizes how a specific foundation contributes to change.

\section{CSR Practices}

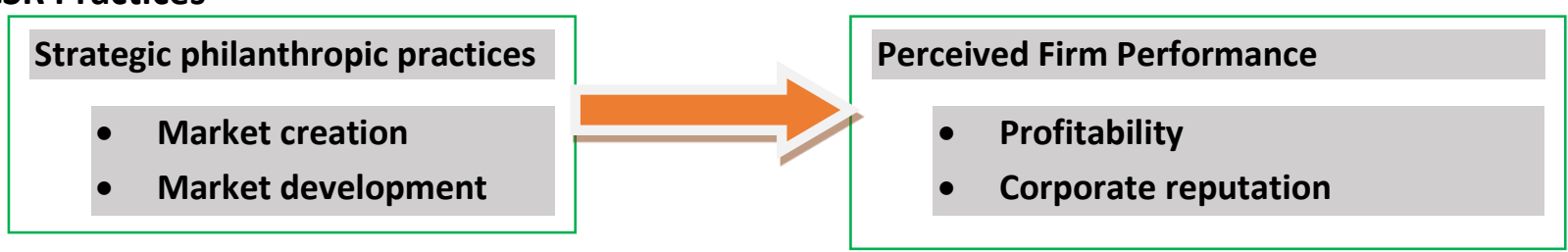

The theory, therefore, suggests that the corporation needs to accept social duties and rights to participate in social co-operation.

\section{Methodology}

Research methodology is a systematic, theoretical analysis of the methods applied to a field of study Irny and Rose (2005). The research philosophy may split the overall research design into sampling design which deals with the method of selecting items to be observed for the given study; the statistical design which concerns with the question of how many items are to be observed and how the information and data gathered were analyzed by using SPSS package as tool; and the operational design which deals with the techniques by which the procedures specified in the sampling, statistical and observational designs can be carried out. The target population is oriented on managers and staff 
INTERNATIONAL JOURNAL OF ACADEMIC RESEARCH IN BUSINESS AND SOCIAL SCIENCES

Vol. 8, No. 7, July 2018, E-ISSN: 2222-6990 (C) 2018 HRMARS

in charge of CSR from the three communication companies. Total targeted population was found by using Yamane's formula $\left(\mathrm{N}=\mathrm{S} / 1+\mathrm{e}^{2 *} \mathrm{~S}\right)$ to find 228 persons as indicated in Table 1.

Table 1: Target Population and Sample frame

\begin{tabular}{lcccc}
\hline \multicolumn{1}{c}{ Company } & $\begin{array}{c}\text { Targeted } \\
\text { population }\end{array}$ & Formula & Percentage & $\begin{array}{c}\text { Sample } \\
\text { size }\end{array}$ \\
\hline $\begin{array}{l}\text { MTN Rwanda's managers and } \\
\text { other staff directly in charge of } \\
\text { CSR }\end{array}$ & 110 & $\mathrm{~N}_{1}=\mathrm{n}^{*} \mathrm{~N}_{1} / \mathrm{N} \%$ & 48.30 & 70 \\
$\begin{array}{l}\text { TIGO Rwanda's managers and } \\
\text { other staff directly in charge of } \\
\text { CSR }\end{array}$ & 80 & $\mathrm{~N}_{1}=\mathrm{n}^{*} \mathrm{~N}_{1} / \mathrm{N} \%$ & 35.23 & 51 \\
$\begin{array}{l}\text { AIRTEL Rwanda's managers and } \\
\text { other staff directly in charge of } \\
\text { CSR }\end{array}$ & 38 & $\mathrm{~N}_{1}=\mathrm{n}^{*} \mathrm{~N}_{1} / \mathrm{N} \%$ & 16.48 & 24 \\
\hline Total & & & & \\
\hline
\end{tabular}

Source: (RURA \& Researcher, 2016)

The level of precision or sampling error was 5\% and 95\% confidence level, total targeted population is 145 managers and other staff directly in charge of CSR from three telecommunication companies in Rwanda, the sample size is determined using the Yamane's formula, $n=\frac{\mathrm{N}}{1+\mathrm{N}(\mathrm{e}) 2}$, and then, sample size, $\mathrm{n}=145\left(\frac{N}{1+N e^{2}}=\frac{228}{1+228 * 0.05^{2}}=145\right)$. This study used stratified sampling method followed by simple random sampling to choose 145 employees from 228 as indicated into Table 1.

The researcher pre-tested them to ten expert respondents. The data from pilot research were tested using Cronbach's Alpha (Coefficient). To validate the ordinal logistic regression, the assumption of proportional odds was check by the test of parallel line. The chi-square was performed and the decision was made based on the $p$-values of chi-square test. To show the level of contribution, the pseudo R-Square was used. Presentation of data was done using appreciation of table and figures with respective description of figures. Time series data from RURA's reports (number of subscribers in internet and mobile telephone, investments in CSR actions and \% of market share of the taken telecom companies from 2012 to 2016) and cross-section data form closed questionnaires are used in this research. In this study, the reliability analysis was conducted for all asked questions in questionnaire and by using SPSS package, the Cronbach Alpha values (range 0 to 1 ) was obtained. The closer to one the better questionnaire is i.e : greaten than 0.9 - Excellent, 0.8-0.9 - Very Good, 0.7 -0.8 - Good George and Mallery, (2003). 
INTERNATIONAL JOURNAL OF ACADEMIC RESEARCH IN BUSINESS AND SOCIAL SCIENCES

Vol. 8, No. 7, July 2018, E-ISSN: 2222-6990 @ 2018 HRMARS

Table 2 Reliability Test Result

Cronbach's Alpha $\quad \mathrm{N}$ of Items

.72

32

Provide the following rules of thumb for Cronbach Alpha values: greaten than 0.9 - Excellent, 0.8-0.9 - Very Good, 0.7 -0.8 - Good, 0.6-0.7 - Acceptable, 0.5-0.6 - Pool, Lower than 0.5 - Unacceptable. Thus a Cronbach Alpha value 0.708 is good. The result, as indicated in table 2, showed that the questions asked have relatively high internal consistency as their Cronbach's Alpha coefficients were between 0.7 and 0.8 . The survey questionnaire was therefore reliable

Information collected from the field is classified into nominal ordinal and scale if applicable to form common data. The instrument is then scrutinized to determine the extent to which they are filled up and whether they have errors, inadequate responses or irrelevancies.

Data coding is done whereby categories of responses have been identified, classified and then recorded. Descriptive and inferential statistics were done and the Statistical Package for Social Sciences (SPSS) was used to analyze data, confidence level of $95 \%$ and a $p$-value of $\leq 0.05$ are required to show evidence of accepting the proposed research question where Spearman's rho correlation and ordinal logistic regression model was applied to ascertain the relationship between the independents and the dependent variables. Those statistical tools were chosen based on the type of variables under study; The following is ordinal logistic regression model for each binomial variable $(\mathrm{j}=1)$, the binomial regression is given by $\ln \frac{p_{j}}{1-p_{j}}=\beta_{0 j}+\beta_{1 j} x_{1}+\beta_{2 j} x_{2}+\cdots(1)$ Here, $p_{j}$ : Probability of success for the variable $(\mathrm{j}=1)$ : "philanthropic strategy" $\beta_{j}$ : The regression coefficient $(\mathrm{j}$ $=0,1$.$) .$

\section{Findings}

\section{Philanthropic corporate social responsibility strategy on perceived firm performance Results}

It was decided in the study to assess the influence of philanthropic CSR strategy practices in the three biggest organization's performance. Philanthropic activities from 2012 - 2016 in that corporation was examined. Primary data were obtained and secondary data were utilized from reports provided by the companies in question, from Rwanda Utility Regulatory Authority (RURA) and from different journals related to SCR. The second part bears questions on core issues in relation to philanthropic activities and effects on companies' performance. 
INTERNATIONAL JOURNAL OF ACADEMIC RESEARCH IN BUSINESS AND SOCIAL SCIENCES

Vol. 8, No. 7, July 2018, E-ISSN: 2222-6990 @ 2018 HRMARS

\section{Philanthropic Practices Results}

Table 3: Philanthropic Practices result in percentage

Source: Survey data

\begin{tabular}{|c|c|c|c|c|c|}
\hline Strategic philanthropic practices & $\begin{array}{l}\text { Strong } \\
\text { agree }\end{array}$ & Agree & Undecided & Disagree & $\begin{array}{l}\text { Strongly } \\
\text { disagree }\end{array}$ \\
\hline Reduce marketing time. & 19.3 & 18.4 & 28.1 & 21.1 & 13.2 \\
\hline Improve productivity & 28.1 & 34.2 & 17.5 & 15.8 & 4.4 \\
\hline $\begin{array}{l}\text { Increase morale of customers and } \\
\text { other stakeholders. }\end{array}$ & 68.4 & 19.3 & 8.8 & 3.5 & 0.0 \\
\hline $\begin{array}{l}\text { Improve facilitates marketing } \\
\text { planning. }\end{array}$ & 31.6 & 38.6 & 12.3 & 14.0 & 3.5 \\
\hline $\begin{array}{l}\text { Increasing firm's image \& reputation, } \\
\text { then gained competition }\end{array}$ & 28.1 & 44.7 & 16.7 & 10.5 & 0.0 \\
\hline $\begin{array}{l}\text { The retention of valuable customers } \\
\text { was impacted }\end{array}$ & 31.6 & 3.5 & 53.5 & 8.8 & 2.6 \\
\hline $\begin{array}{l}\text { Facilitate people to be familiar with } \\
\text { the business. }\end{array}$ & 15.8 & 30.7 & 31.6 & 14.0 & 7.9 \\
\hline Philanthropic practices & 32 & 27 & 24 & 13 & 5 \\
\hline
\end{tabular}

Great number of respondents are agreed that philanthropic practices can increase morale of companies' customers \& other stakeholders (87.7\%) followed by firm's image \& reputation and gained market competition with 83 respondents $(72.8 \%)$, improved marketing planning with 80 respondents (70.2\%) and improved company's productivity and profitability with frequency of 71 respondents (62.3\%) while (46.5\%) show that philanthropic actions do not facilitate people to be familiar with the business, $37,7 \%$ respondents representing are against said that philanthropic practices do not reduce marketing time and $35.1 \%$ responses from managers and CSR staff were against to the idea that philanthropic practices impact positively retention of valuable customers.

Results to the Firm's perceived performance from philanthropic

Table 4 Distribution of respondents regarding firm's perceived performance

\begin{tabular}{lccccc}
\hline $\begin{array}{l}\text { CSR actions permit to the firm to have } \\
\text { a: }\end{array}$ & $\begin{array}{c}\text { Strong } \\
\text { agree }\end{array}$ & Agree & Undecided & Disagree & $\begin{array}{c}\text { Strongly } \\
\text { disagree }\end{array}$ \\
\hline $\begin{array}{l}\text { Improved organizational profitability } \\
\begin{array}{l}\text { Improved customers' retention and } \\
\text { gained confidence from them }\end{array}\end{array}$ & 20.2 & 21.9 & 39.5 & 12.3 & 6.1 \\
$\begin{array}{l}\text { Increased firm's image, reputation and } \\
\text { goodwill }\end{array}$ & 33.3 & 42.1 & 13.2 & 7.9 & 0.0 \\
$\begin{array}{l}\text { Contributed competitive advantage } \\
\text { Perceived firm's performance }\end{array}$ & $\mathbf{2 8 . 1}$ & 32.6 & 10.5 & 3.5 & 0.0 \\
\hline
\end{tabular}

Source: Survey data 
INTERNATIONAL JOURNAL OF ACADEMIC RESEARCH IN BUSINESS AND SOCIAL SCIENCES

Vol. 8, No. 7, July 2018, E-ISSN: 2222-6990 (C) 2018 HRMARS

Majority of respondents revealed that philanthropic's actions carried out by MTN, TIGO and AIRTEL in Rwanda to the society can raise clients (90 responses representing 78.9\%), increase company's image and reputation (98 responses representing $85.9 \%$ ), promote competition in term of competitive advantage (74 responses representing 64.9\%) and finally improve organizational profitability (48 responses representing $42.1 \%$ ); thus perceived firm's performance may attempt at $68 \%$ given by 78 respondents

\section{Inferential Statistics}

\section{The ordinal logistic regression analysis result}

The use of ordinal logistic regression required the verification of correct classified case, if the cases under study are not correctly classified the use of model 1 can be a menace to our final result Pallant \& Manual, (2010). The following table presents the correctly classified cases.

Table 5: Correctly Classified cases

\begin{tabular}{|c|c|c|c|c|c|c|c|}
\hline & & \multicolumn{5}{|c|}{ Predicted Response Category } & \multirow[b]{3}{*}{ Total } \\
\hline & & Strongly & & & & Strongly & \\
\hline & & Agree & Agree & Undecided & Disagree & Disagree & \\
\hline \multirow{5}{*}{$\begin{array}{l}\text { perceived } \\
\text { firm's } \\
\text { performance }\end{array}$} & $\begin{array}{l}\text { Strongly } \\
\text { Agree }\end{array}$ & 34 & 0 & 0 & 0 & 0 & 34 \\
\hline & Agree & 2 & 42 & 0 & 0 & 0 & 44 \\
\hline & Undecided & 0 & 3 & 20 & 1 & 0 & 24 \\
\hline & Disagree & 0 & 0 & 0 & 8 & 1 & 9 \\
\hline & $\begin{array}{l}\text { Strongly } \\
\text { Disagree }\end{array}$ & 0 & 0 & 0 & 0 & 3 & 3 \\
\hline Total & & 36 & 45 & 20 & 9 & 4 & 114 \\
\hline
\end{tabular}

\section{Data analyzed by the Author, 2017}

The table 5 shows the total number of cases under study (114) and the correctly classified cases were obtained by adding the elements of diagonal in the table, which gives 107 correctly classified cases with percentage of 93.8. This result ensure us that the use of the model (1), will include $93.8 \%$ of the total number of cases under study.

Validation of Ordinal logistic regression model (1)

Table 6: Test of Parallel Lines output

\begin{tabular}{lrllll}
\hline Model & $\mathbf{- 2}$ Log Likelihood & Chi-Square & d.f & \multicolumn{1}{l}{ Sig. } \\
\hline Null Hypothesis & .000 & & & \\
General & .000 & .000 & 39 & 1.000 \\
\hline
\end{tabular}

The Table 6 shows the output of parallel lines test (chi-square 0.000, d.f $=39$ and $p$-value $=1.000$ ), since the $p$-value is greater than 0.05 significance level, therefore, we accepted, the null hypothesis, hence the the assumption of proportional odds is met, we can use the model (1) for further analysis. 
INTERNATIONAL JOURNAL OF ACADEMIC RESEARCH IN BUSINESS AND SOCIAL SCIENCES Vol. 8, No. 7, July 2018, E-ISSN: 2222-6990 (C) 2018 HRMARS

Table 7: Chi-square test

\begin{tabular}{lrrrr}
\hline Model & $\mathbf{- 2}$ Log Likelihood & Chi-Square & d.f & Sig. \\
\hline Intercept Only & 277.229 & & & \\
Final & .000 & 277.229 & 13 & .000 \\
\hline
\end{tabular}

Link function: Logit.

Source: Data analyzed by Author, 2017

The table 7 represents the Goodness of fil for model(1), the test result are given by Chi-square value(277.229), $d f=13$ and $p$-value (0.000), since the $p$-value is less than the 0.005 significance level, therefore, the model (1) is well fitted, the predictor variables explain well enough the response variable.

Table 8: Pseudo R-square

\begin{tabular}{|c|c|}
\hline \begin{tabular}{c|c|} 
Cox and Snell \\
Nagelkerke
\end{tabular} & .912 \\
& .977 \\
McFadden & .899 \\
\hline
\end{tabular}

Link function: Logit.

Source: Data analyzed by Author, 2017

The table 8 shows that the different values for pseudo R-square, we have reported Nagelkerke because is normalized with the range (from 0 to 1), Pallant, \& Manual, (2010). Therefore, the independent variables explain $97.7 \%$ changes in the response variable. In other word, the variance of perceived firm's performance is influenced by "philanthropic" at $97.7 \%$. 
INTERNATIONAL JOURNAL OF ACADEMIC RESEARCH IN BUSINESS AND SOCIAL SCIENCES Vol. 8, No. 7, July 2018, E-ISSN: 2222-6990 @ 2018 HRMARS

Table 9 Contribution of philanthropic to the response variables results

\begin{tabular}{|c|c|c|c|c|}
\hline Parameters & B & $\operatorname{Exp}(B)$ & $1+\operatorname{Exp}(B)$ & Probability \\
\hline$\left[X \_1=1\right]$ & 37.476 & $1.88 \mathrm{E}+16$ & $1.88 \mathrm{E}+16$ & 1.0 \\
\hline$\left[X \_1=2\right]$ & 37.476 & $1.88 \mathrm{E}+16$ & $1.88 \mathrm{E}+16$ & 1.0 \\
\hline [X_1=3] & 17.390 & 35689199.18 & $3.57 \mathrm{E}+07$ & 1.0 \\
\hline$\left[X \_1=4\right]$ & 17.390 & 35689201.97 & $3.57 \mathrm{E}+07$ & 1.0 \\
\hline$\left[X \_1=5\right]$ & & & & 0 \\
\hline Average & & & & 0.8 \\
\hline [X_2=1] & 54.751 & $6.00167 \mathrm{E}+23$ & $6.00 \mathrm{E}+23$ & 1.0 \\
\hline [X_2=2] & 32.486 & $1.28339 \mathrm{E}+14$ & $1.28 \mathrm{E}+14$ & 1.0 \\
\hline [X_2=3] & 14.344 & 1696232.219 & $1.70 \mathrm{E}+06$ & 1.0 \\
\hline [X_2=4] & 14.344 & 1696232.146 & $1.70 \mathrm{E}+06$ & 1.0 \\
\hline [X_2=5] & & & & 0 \\
\hline Average & & & & 0.8 \\
\hline [X_3=1] & & & & 0 \\
\hline [X_3=2] & $1.622 \mathrm{E}-08$ & 1 & $2.00 \mathrm{E}+00$ & 0.5 \\
\hline [X_3=3] & $1.081 \mathrm{E}-08$ & 1 & $2.00 \mathrm{E}+00$ & 0.5 \\
\hline [X_3=4] & & & & 0 \\
\hline [X_3=5] & & & & 0 \\
\hline Average & & & & 0.2 \\
\hline [X_4=1] & 20.841 & 1124763305 & $1.12 \mathrm{E}+09$ & 1.0 \\
\hline [X_4=2] & 20.841 & 1124763251 & $1.12 \mathrm{E}+09$ & 1.0 \\
\hline [X_4=3] & 20.841 & 1124763238 & $1.12 \mathrm{E}+09$ & 1.0 \\
\hline [X_4=4] & & & & 0 \\
\hline [X_4=5] & & & & 0 \\
\hline Average & & & & 0.6 \\
\hline
\end{tabular}

Source: Data analyzed by Author, 2017

Philanthropic practices, coded as X_2 with categories level 1, 2, 3, 4 and 5 which are statistical significant with p-value of 0.000 per each categorical level as shown in table 9 . The contribution of this variable to the perceived firm's performance is $80 \%$ as indicated in table. To conclude, there is a signification influence of Philanthropic practices to the perceived firm's performance.

\section{Correlation Results}

The following are results that demonstrate the degree of relationship between variables under study. The spearman' rho correlation coefficient was used determine the relation between them. It is used when the variables are not measurable and its range from 0 to 1 . 
INTERNATIONAL JOURNAL OF ACADEMIC RESEARCH IN BUSINESS AND SOCIAL SCIENCES

Vol. 8, No. 7, July 2018, E-ISSN: 2222-6990 (C) 2018 HRMARS

Table 10 Spearman's rho Correlation results

\begin{tabular}{ll}
$\begin{array}{ll}\text { Perceived firm's } & \text { Philanthropic } \\
\text { performance } & \text { Practices }\end{array}$ \\
\hline
\end{tabular}

\section{Perceived}

firm's

1

$.946^{* *}$

performance

Philanthropic

Practices

** Correlation is significant at the 0.01 level (2-tailed). Source: Data analysis

Given the results from correlation analysis, the philanthropic is strongly positive correlated as showed by the Pearson correlation coefficients which are greater than 0.75 as appeared in table. Thus, there is positive relationship between the independent and dependent variable.

\section{Analysis of Variance Results}

The following are analysis of variance for philanthropic practices and different independent variables, the purpose of this test, is to check whether, there is a statistical significant between groups.

Table 11 : Perceived firm's performance vs Philanthropic Practices result

\begin{tabular}{|c|c|c|c|c|c|c|}
\hline & & $\begin{array}{l}\text { Sum of } \\
\text { Squares }\end{array}$ & df & $\begin{array}{l}\text { Mean } \\
\text { Square }\end{array}$ & $\mathbf{F}$ & Sig. \\
\hline $\begin{array}{l}\text { Perceived } \\
\text { firm's }\end{array}$ & $\begin{array}{l}\text { Between } \\
\text { Groups }\end{array}$ & 105.580 & 4 & 26.395 & 223.283 & .000 \\
\hline $\begin{array}{l}\text { performance } \\
*\end{array}$ & $\begin{array}{l}\text { Within Groups } \\
\text { Total }\end{array}$ & 12.885 & 109 & .118 & & \\
\hline $\begin{array}{l}\text { Philanthropic } \\
\text { Practices }\end{array}$ & & 118.465 & 113 & & & \\
\hline
\end{tabular}

Source: Data analysis by Author

The results in the table 11 shows that there is a statistical significant different between the Perceived firm's performance and Philanthropic Practices as revealed by ANOVA ( $F=223.283$, d. $f=4$ and $p$ value( 0.00$)$ which is less than $0.05 \%$ level of significance).

Performance in targeted telecom companies due to philanthropic practices

Table 12 a: Subscribers in mobile telephone June 2012 - June 2016

\begin{tabular}{|c|c|c|c|c|c|}
\hline Years & MTN Rwanda & TIGO Rwanda & AIRTEL Rwanda & TOTAL & \% change \\
\hline 2012 & $3,033,421$ & $1,615,585$ & 110,304 & $4,759,310$ & 7.04 \\
\hline 2013 & $3,599,540$ & $1,900,693$ & 915,110 & $6,415,343$ & 34.80 \\
\hline 2014 & $4,346,721$ & $2,295,233$ & $1,105,065$ & $7,747,019$ & 20.76 \\
\hline 2015 & $3,957,986$ & $2,887,328$ & $1,336,679$ & $8,181,993$ & 5.61 \\
\hline 2016 & $3,988,604$ & $3,110,540$ & $1,183,964$ & $8,293,108$ & 1.36 \\
\hline General increasing & $7.81 \%$ & $17.98 \%$ & $189.98 \%$ & & 13.91 \\
\hline
\end{tabular}

Source: RURA, operators' return 
INTERNATIONAL JOURNAL OF ACADEMIC RESEARCH IN BUSINESS AND SOCIAL SCIENCES Vol. 8, No. 7, July 2018, E-ISSN: 2222-6990 (C) 2018 HRMARS

In the year 2016, mobile telephone subscribers increased by $1.4 \%$ from $8,181,993$ subscriptions recorded in 2015 to 8,293,108 subscribers recorded in 2016. General evolution was $13.91 \%$ for the whole period of the study and MTN Rwanda dominated the market by $48.2 \%$ followed by TIGO Rwanda with $37.5 \%$ and AIRTEL Rwanda by $14.3 \%$.

Table 12 b: Subscribers in internet June 2012 - June 2016

\begin{tabular}{|c|c|c|c|c|c|c|c|c|}
\hline & \multicolumn{2}{|c|}{ MTN Rwanda } & \multicolumn{2}{|c|}{ TIGO Rwanda } & \multicolumn{2}{|c|}{ AIRTEL Rwanda } & \multicolumn{2}{|l|}{ TOTAL } \\
\hline Years & Count & Increment & Count & increment & Count & increment & & Change (\%) \\
\hline 2012 & 505263 & & 235234 & & 8874 & & 749371 & 9.02 \\
\hline 2013 & 517938 & 2.508595 & 562000 & 138.911 & 198688 & 2138.99 & 1278626 & 70.63 \\
\hline 2014 & 895561 & 72.90892 & 971749 & 72.90907 & 343549 & 72.9088 & 2210859 & 72.91 \\
\hline 2015 & 1490117 & 66.38922 & 1505786 & 54.95627 & 525920 & 53.0844 & 3521823 & 59.3 \\
\hline 2016 & 1558669 & 4.600444 & 1505773 & -0.00086 & 893866 & 69.9624 & 3958308 & 12.39 \\
\hline G. inc & ing (\%) & 36.6 & & 66.7 & & 583.7 & & 44.85 \\
\hline
\end{tabular}

\section{Source: Field data 2016}

The general dispatched internet subscription was 39.4\% for MTN Rwanda, 38\% for TIGO Rwanda and 22.6\% for AIRTEL Rwanda while general increasing of internet subscription in each telecommunication company in Rwanda was characterized by the very high increasing in AIRTEL by $583.74 \%$, middle increase return in TIGO by $66.69 \%$ and small increase return in MTN by $36.60 \%$ See table above.

Table 13 a Market Share of mobile telephones between MTN, TIGO and AIRTEL Rwanda

\begin{tabular}{cccc}
\hline Years & $\begin{array}{c}\text { MTN Rwanda } \\
\text { (\%) }\end{array}$ & $\begin{array}{c}\text { TIGO Rwanda } \\
\text { (\%) }\end{array}$ & $\begin{array}{c}\text { AIRTEL Rwanda } \\
\text { (\%) }\end{array}$ \\
\hline 2012 & 63.7 & 33.9 & 2.3 \\
2013 & 56 & 30 & 14 \\
2014 & 51.3 & 32.5 & 14.72 \\
2015 & 49 & 35 & 16 \\
2016 & 46 & 36 & 18 \\
General trend & $\mathbf{5 3 . 2}$ & $\mathbf{3 3 . 4 8}$ & $\mathbf{1 3 . 3 2}$ \\
\hline
\end{tabular}

Source: Secondary data, RURA, operators' return

For the period of the study, MTN Rwanda dominated the market but in the decreased manner, followed by TIGO Rwanda (first decreasing and then after increasing manner) and AIRTEL Rwanda in increasing manner. The average variation during the period of the study was 53.2\% for MTN Rwanda, 33.48\% for TIGO Rwanda and 13.32\% for AIRTEL Rwanda. 
INTERNATIONAL JOURNAL OF ACADEMIC RESEARCH IN BUSINESS AND SOCIAL SCIENCES Vol. 8, No. 7, July 2018, E-ISSN: 2222-6990 @ 2018 HRMARS

Table 13 b. Market share of internet between MTN, TIGO and AIRTEL Rwanda

\begin{tabular}{cccc}
\hline Years & MTN Rwanda (\%) & $\begin{array}{c}\text { TIGO Rwanda } \\
\text { (\%) }\end{array}$ & AIRTEL Rwanda (\%) \\
\hline 2012 & 12 & - & - \\
2013 & 40 & 44 & 16 \\
2014 & 42 & 43 & 16 \\
2015 & 43 & 42 & 15 \\
2016 & 39.64 & 36.55 & 23.58 \\
General trend & $\mathbf{3 5 . 3}$ & $\mathbf{4 1 . 4}$ & $\mathbf{1 7 . 6}$ \\
\hline
\end{tabular}

Source: Secondary data, RURA, operators' return

There is a domination of TIGO Rwanda in share market of internet in term of $41.4 \%$ of the total market, followed by MTN Rwanda with 35.3\% and AIRTEL Rwanda by $17.6 \%$, the difference from $100 \%$ (to mean $5.7 \%$ ) is dispatched among other telecom companies existing in the country. MTN Rwanda had positive trend of market share from 2012 to 2015 and negative trend in 2016; decreasing share market to TIGO Rwanda for all period of the study and, constant - decreasing and increasing considerably for AIRTEL Rwanda in 2016.

\section{Discussion of the Results}

Discussion focuses around the philanthropic practices, in accomplishment of the CSR activities in three telecom companies in Rwanda such as MTN Rwanda, TIGO Rwanda and AIRTEL Rwanda. Companies can no longer achieve economic prosperity without impacting on the life of all the stakeholders and agents. In an attempt to touch the lives of majority of stakeholders and agents if not the whole, telecom companies undertake corporate social responsibility been it voluntary or mandatory. From the study it was found out that, all the telecommunication has a common objective of eradicating poverty and raising standard of living of stakeholders through education, economic empowerment, health and other activities like environment protection and government priorities. The government of Rwanda has also been very supportive to these companies in their achievement in CSR activities. The ministry of education as well as heal health ministry has good partnership with the companies in realizing the country's vision 2020 of knowledge economy. CSR activities of MTN, TIGO and AIRTEL in Rwanda are not only just voluntary actions of the companies but also a necessary condition for the achievement of the country vision 2020. Qualitative raw data are from interview and open questionnaires while quantitative data are from closed questionnaires and reports from RURA and targeted telecoms industry. This section discusses the analysis and interpretation of data and finally the discussion of the findings.

\section{Conclusions}

To evaluate the influence of Philanthropic practices to performance of telecommunication sector in Rwanda. The study concludes that using CSR activities as philanthropic strategy practices is significant and positively linked to firm performance in telecommunication sector in Rwanda. It revealed that CSR practices are benefit to the firm's successful through increased morale of company's customers in mobile and internet subscribers and other stakeholders because it improves marketing planning and gives to the organization a good image and reputation; as consequence, that firms that emphasized philanthropic practices outlook enhanced their performance. 
From the above discussion it can be deduced that, all the telecommunication companies in Rwanda has the focus of improving the education, health and economic empowerment system of the country because they believe that the above mentioned factors are the backbone of a growing economy of the country like Rwanda. Generally, involvements in CSR activities by MTN, TIGO and AIRTEL in Rwanda had several construct motives and were in line with the agency theory assumption: the companies strived to portray themselves as highly socially responsible companies to compete with rivals. One of the primary motivating factors is the belief that CSR actions can increase long term profitability and sustainability of the company as well as enhance the image and reputation of the organization. Managers believed also that CSR practices can increase customers' confidence to the companies and their products. In combination with other factors like quality management, committed staff, quality and quantity of products, business environment, etc., philanthropic practices may improve more perceived firm's performance.

\section{Recommendations}

It recommends that to the stakeholders and partners, telecommunication companies in question should labor more in informing their stakeholders and partners about their different philanthropic investments as they have been established to be a great tool for market performance and profitability because there were no clear mechanisms for informing public in general about their taken Corporate Social Responsibility actions. To the companies' managers, The telecommunication companies' managers should inculcate beneficiaries in planning of Corporate Social Responsibility actions oriented to them in order to reach their priorities and needs and increase the portion allocated to the CSR actions, company resources before being invested in corporate social responsibility should first be analyzed for impact on the different societies they are intended for to have a great market impact and make the investments equally beneficial to the organization. The different media channels should be balanced and used to the same extent in informing the public about the different corporate social investments by the organization to maximize that impact of the different social investments by the company.

\section{Acknowledgement}

I wish to extend my heartfelt appreciation to my supervisors Prof. G.S. Namusonge and Dr.Julius Warren Kule their direction; I would not have been able to do this research. I thank my extended family for their moral support. May the almighty God reward them for the prayers and love. I acknowledge the administration of JKUAT for giving me all required documents which helped me during the research.

\section{References}

Behrens, T. R. (2009). Editorial. The Foundation Review, 1(1), 4-5.

Brest, P. (2010). The power of theories of change. Stanford Social Innovation Review. http://ssir.org/articles/entry/the_power_of_theories_of_change

Carroll, A. B. (1979). Three-Dimensional Conceptual Model of Corporate Performance. Journal of Academy of Management, 4(4), 497-505.

Carroll, A. B. (1999). Corporate Social Responsibility: Evolution of a Definitional Construct. Sage journal, pp.268-295.

Carton, R. B., \& Hofer, C. W. (2006). Measuring Organizational Performance: Metrics for Entrepreneurship and Strategic Management Research. Cheltenham, UK; Northampton 
INTERNATIONAL JOURNAL OF ACADEMIC RESEARCH IN BUSINESS AND SOCIAL SCIENCES

Vol. 8, No. 7, July 2018, E-ISSN: 2222-6990 @ 2018 HRMARS

Colby, S., Stone, N., \& Carttar, P. (2004). Zeroing in on impact. Stanford Social Innovation Review. Available

Dagwom, Y. D. (2014). Corporate social responsibility and community relations in Nigeria. Journal of Business Management and Economics, 2(7), 121-127.

Davis, K. (1960). Can business afford to ignore corporate social responsibility? Journal of California Management , 2(4), 70-76.

DeGeorge, R. T. (2010). Business Ethics. 7th. Upper Saddle River: Pearson Education, Inc. 200. Print

Forti, M. (2012). Six theory of change pitfalls to avoid. Stanford Social Innovation Review, http://ssir.org/articles/entry/six_theory_of_change_pitfalls_to_avoid

Friedman, M. (1970). The Social Responsibility of Business is to Increase its Profits. The New York Times Magazine, 13(13), 32-33.

Githinji, R. K. (2015). The Corporate Social Responsibility Strategies and Activities Employed By the Equity Bank in Kenya to Improve Its Performance. Journal of Business and Management, 17(1), 28-32.

Guus, W., Gemma, B., Ine, C., \&Femke, N. (2013). Corporate Social Responsibility in the agro-food sector. Amsterdam: Utrecht University.

Hamid, F., \& Ruhaya, A. (2011). Corporate Social Responsibility by the Malaysian Telecommunication Firms. International Journal of Business and Social Science, 2(5), 198 - 208.

Husted, B. W., \& Allen, D. B. (2001). Toward a model of corporate social strategy formulation. New York: Academy of Management.

John, E. N., Victor, A. \& Umoh, M. . (2015). Corporate Social Responsibility and Mobile Telecommunication Competitiveness in Nigeria: The Case of MTN Nigeria. American Journal of Industrial and Business Management, 5(5), 527-537.

Maimunah, I. (2009). Social responsibility and its role in community development. The Journal of International Social Research, 2(9), pp.64 - 72.

Margolis, J. D., \& Walsh, J. P. (2003). Misery loves companies: Rethinking social initiatives by business. Administrative Science Quarterly, 48(1), 268-305.

Patton, M. Q. (2011). Developmental evaluation: Applying complexity concepts to enhance. innovation and use. NewYork: Guildford Press.

Patton, M. Q. (2011). Developmental evaluation: Applying complexity concepts to enhance. innovation and use. NewYork: Guildford Press.

Patrizi, P., \& Patton, M. Q. (Eds.) (2010). Evaluating Strategy, New Directions for Evaluation, Number 128.

Rwanda Utilities and regulatory authority. (2015). Statistics And Tariff Information In Telecom Sector As Of March 2015 . Kigali- Rwanda: Economic and Market Analysis Section (Rwanda Utilities and regulatory authority).

Secchi, D. (2005). The Italian experience in social reporting: An empirical analysis. Journal of Corporate Social Responsibility and Environmental Management, 13(1), 135-149.

Shoukat,M. \& Muhammad, N. (2014). Impact of corporate social responsibility on the financial performance of banks in Pakistan. International Letters of Social and Humanistic Sciences, 21(9), 9-19.

Sweta, S. (2010). Philanthropy to Corporate Social Responsibility: An Indian Perspective. Journal of of International Comparative Management, 11(5), 990 - 1000. 
INTERNATIONAL JOURNAL OF ACADEMIC RESEARCH IN BUSINESS AND SOCIAL SCIENCES

Vol. 8, No. 7, July 2018, E-ISSN: 2222-6990 @ 2018 HRMARS

Tigo, R. (2015). Tigo's Donation Tour highlights need for businesses to support survivors. Kigali Rwanda: Tigo Rwanda. 